\title{
The Impact of the Openness of Firms' External Search Strategies on Exploratory Innovation and Exploitative Innovation
}

\author{
Mingfeng Tang ${ }^{1,2, *}$, Peng $X u^{1}$, Patrick Llerena ${ }^{2}$ and Asghar Afshar Jahanshahi ${ }^{3,4, *(D)}$ \\ 1 School of Business Administration, Southwestern University of Finance and Economics, \\ Chengdu 610074, China \\ 2 Bureau d'Économie Théorique et Appliquée, University of Strasbourg, 67085 Strasbourg, France \\ 3 CENTRUM Católica Graduate Business School, Lima 15023, Peru \\ 4 Pontificia Universidad Católica del Perú, Lima 15023, Peru \\ * Correspondence: tang@swufe.edu.cn (M.T.); afshar@pucp.edu.pe (A.A.J.)
}

Received: 26 June 2019; Accepted: 1 September 2019; Published: 5 September 2019

\begin{abstract}
Innovation activities of private firms are crucial for sustainable economic growth in every society. Therefore, the majority of firms around the world spend large amounts of capital (money, time, and human resources) in searching for novel innovative opportunities in the marketplace. In our study, we sought to understand how the openness of firms' external search strategies (external search breadth and external search depth) affects firms' innovation capabilities as measured by awareness, decision-making, interpretation, and implementation capability. Furthermore, using survey data collected from 112 Chinese manufacturing firms over a six-month period, this study conducted an empirical analysis about the association between firms' innovation capabilities on the type of innovation (exploratory innovation vs. exploitative innovation). This study also provides important managerial insights for manufacturing companies.
\end{abstract}

Keywords: external search; innovation capability; sustainable economic growth; exploratory innovation; exploitative innovation; sustainable competitive advantage

\section{Introduction}

China aims to become an innovation society by 2020 and an innovation power by 2050 . These ambitious objectives cannot be achieved without the contribution of Chinese manufacturing firms. According to the Chinese National Bureau of Statistics, secondary industries contributed $40.7 \%$ of the gross domestic product (GDP) in 2018, and the manufacturing industry made up $72.4 \%$ of that contribution (data from the Chinese National Bureau of Statistics: http://www.stats.gov.cn/tjsj/zxfb/ 201901/t20190122_1646082.html). As the cornerstone of China's economy, manufacturing firms are required to shift from low-cost production to more sustainability-oriented and knowledge-intensive production that will help them to upgrade their innovation capability. Innovation is not merely an alternative but rather a necessity for business sustainability and competitiveness [1-4]. To enhance their competitiveness, firms need the capability to identify, absorb, and integrate new potential sources of innovation [5].

With the continuous reduction of product life cycles and fierce market competition, relying on internal sources for innovation cannot meet the requirements of a firm's development. A completely closed innovation process does not exist and most companies implement open innovation to varying degrees [6]. Therefore, it is important for firms to maintain cooperation with external innovation sources during the innovation process. Achieving innovation through the use and commercialization of complementary internal and external innovation resources was originally viewed as open innovation 
by the authors of $[7,8]$. Open innovation is seen as a solution for firms to break the bottleneck of closed innovation and gain sustainable competitive advantages [3]. Firms' external knowledge search has been practiced as a part of their innovation strategies. The search breadth and depth and firms' research and development $(R \& D)$ capabilities affect their marginal returns from $R$ \& D investments [9]. Hence, it makes sense to introduce the concept of "the degree of innovation openness" to characterize the differences that exist in the innovation activities of firms.

Previous research has confirmed that with a highly uncertain environment, open innovation has evolved into a complex activity [7,10-12]. This complexity makes it very important for firms to choose an appropriate type of innovation based on the degree of innovation openness. A low degree of innovation openness means that firms cannot break through the limitations of traditional closed innovation and realize their own fundamental innovation advantages. Excessive openness may cause problems, such as internal distractions and excessive dependence on external technologies. Firms can fail to select a truly suitable innovation type for their business development [13]. However, the existing literature keeps rather silent about how the degree of innovation openness influences the choice of firms' innovation type and in what way the degree of innovation openness effects innovation types, namely exploitative innovation and exploratory innovation. The choice of innovation type is particularly important for firms, because the particular innovation type must be consistent with a firm's strategy. It is related to a firm's future competitiveness and-together with strategic orientation-forms the core content of a business strategy [14,15]. Further research is needed on how the openness of a firm's external search strategy influences its innovation capability and innovation type (i.e., exploitative innovation and exploratory innovation).

The structure of this paper is organized as follows: first, we present a literature review and propose our research hypotheses; second, we propose our theoretical framework and introduce our research methodology; third, we outline our research results; and finally, we share our conclusions and provide some management implications.

\section{Literature Review and Hypotheses Development}

\subsection{The Openness of Firms' External Search Strategies}

In recent years, many scholars have focused attention on the phenomenon of organizational ambidexterity in pursuing both exploration and exploitation [16-20]. Several factors, such as organizational structure, processes, strategies, and capabilities, influence the choice of exploration or exploitation $[20,21]$. When a firm implements an external search strategy, it needs to consider the openness of its external search, the corresponding innovation capability, and innovation type. We hereafter clarify the understanding of the relationships among the openness of firms' external search strategies, innovation capabilities, and innovation types.

Laursen and Salter [10] were the first to quantitatively define the degree of innovation openness, namely as the number of different external knowledge resources that companies can use for innovation activities [22]. This measurement method considered only the breadth of openness without considering the depth. Later, they expanded it into two indicators-the depth of openness and the breadth of openness. Openness breadth refers to the number of companies that partner with external entities; openness depth refers to the degree of cooperation between the two parties [10]. Since then, Keupp and Gassmenn [23] and Chen and Chen [24] have both used methods similar to Laursen and Salter [10] for measuring breadth and improved the measurement of depth, that is, the frequency at which firms use external innovation sources. However, the disadvantage of this method is clear in that the two indicators should be measured separately and cannot be integrated. Yan and Cai [25] added internal innovation resources to the criteria of innovation openness degree from the work of [10]. They defined the degree of innovation openness as the total of all a firm's external resources and all resources within its internal non- $\mathrm{R} \& \mathrm{D}$ sector that can be used for innovation activities in the process of open innovation. 
In addition, they defined the importance of different innovation resources in the open innovation activities of the firm [26].

The research goal of this paper was to investigate Chinese manufacturing firms and explore how the openness of their external search strategies influences exploitative innovation and exploratory innovation. We adopted Yan's and Cai's [25] definition of innovation openness and divided the openness of firms' external search strategies into external search breadth and external search depth. The openness of firms' external search strategies refers to the external innovation source dimension, measured by external search breadth and external search depth. External search breadth means the number of external innovation sources with which a firm cooperates. External search depth means the degree of cooperation with innovation resources outside a firm and cooperation with internal non-R \& $\mathrm{D}$ departments/staff and other member firms in a company group. Our research focused on studying the number of external innovation sources with which a firm cooperates and the degree of cooperation with innovation resources inside and outside a firm.

\subsection{Innovation Capability}

Innovation capability is the foundation for companies to effectively carry out innovation activities and is the most important factor affecting corporate performance [16]. The definition of innovation capability mainly focuses on either the process concept or the element concept. The process concept defines innovation capability from the perspective of the technological innovation process. The capability building needs to search, learn, and exchange information processes across different organizational units and external parties [27]. Wei et al. [28] view innovative capability as a systematic and integrative function arising from the combination of product innovation capability and process innovation capability that supports the implementation of a firm's innovation strategy [17]. The element concept defines innovation capability by the elements involved in innovation, which can be divided into broad innovation capability and narrow innovation capability. Narrow innovation capability refers mainly to the capability of technological innovation, namely the capability to effectively absorb, acquire, and improve existing technologies, as well as to create the skills and knowledge needed for new technologies [29], which will be transformed into new knowledge, new processes, or new systems $[28,30]$. Broad innovation capability is not only related to a firm's technological capability, but also to non-technical elements, namely the capability to support a firm's innovation strategy, such as manufacturing, marketing, and human resource capabilities [31-33].

Another understanding of innovation capability based on the knowledge creation process was proposed by Zhang et al. [13]. They suggested that firms should first be aware of the internal and external changes-correctly interpreting the effect of dynamic information on firm performance-and then take actions in effective response to the changes and keep dynamic adaptability between the firm itself and the environment. From their point of view, a firm's innovation capability is composed of various capabilities: to monitor, collect, and deal with a firm's information and knowledge; to understand and evaluate information with actual or potential business value that may be applicable or achievable; to select a firm's future innovation actions or innovation orientation based on agreement arising from various interactions; and to take actions for achieving innovation objectives. These capabilities are put together to form the process of knowledge creation. They comprise highly overlapping parts of a firm's absorptive capability, both potential absorptive capacity and realized absorptive capacity $[34,35]$. The main difference between innovation capability and absorptive capability lies in the level of actions taken. Innovation capability emphasizes more select and take actions for achieving innovation objectives.

This study employed [13] an understanding of a firm's innovation capability to analyze how the capability influences the choices of firms' innovation types. A firm's innovation capability was measured by four aspects: awareness, interpretation, decision making, and implementation. 


\subsection{Innovation Types}

Firms usually use two different innovation types to renew themselves in a highly competitive market, some firms prefer to renew by exploiting existing competencies and other firms prefer to explore new ones [36]. Exploitative innovation refers to refining a firm's existing knowledge, technologies, and products $[37,38]$, and doing better what the firm is already doing, which leads to more certain and proximate benefits [39]. Exploitative innovation has been viewed as associated with mechanistic structures, path dependence, and routinization [40], and produces progressive products and/or services [35]. Exploratory innovation describes firms' search for novel knowledge, use of unfamiliar technologies, and the creation of products with an unknown demand, which leads to uncertain and distant benefits $[39,41]$ and the change of the game rules in the industry. Exploratory innovation has long been associated with organic structure, improvisation, and autonomy [40].

The existing literature either studies the organizational ambidexterity in the use of exploitation and exploration [16,17,40,42] or calls for studying exploration and exploitation separately $[21,43,44]$. Some research findings support the positive linkage between ambidexterity and firm performance [42,45], as well as firms' new product performance [17,46]. Others have reported effects that were insignificant [47], negative [44,48], or mixed [49]. As such, there has not been agreement about the effect of balance on firm performance, and most scholars advocate to separate exploitation from exploration [42]. This provides researchers some space to explore what degree of openness of firms' external search strategies influences a firm's choice about exploitative or exploratory innovation and what mediates the relationship between the openness of firms' external search strategies and exploratory/exploitative innovation.

\subsection{The Openness of Firms' External Search Strategies and Innovation Types}

Many scholars recognize organizational ambidexterity in the use of exploration and exploitation $[35,42,50]$. Several factors, such as organizational structure, processes, strategies, and capabilities, influence the choice of exploration or exploitation $[20,51,52]$. Therefore, when a firm implements an external search strategy, it needs to consider the openness of its external search, the corresponding innovation capability, and innovation types. The openness of a firm's external search is measured by the breadth and depth of the outside search. The breadth of the external search refers to the number of external sources of cooperation when a firm conducts an open innovation strategy. The strategy of collaborating with other organizations benefits a firm from risk sharing; access to new markets; and/or acquiring knowledge, technologies, and capability building [53]. The depth of external search describes the intensity of open innovation activities in an innovation network and generally reflects the quantity and frequency of use of external technical knowledge by enterprises. In spite of uncertain quality and quantity of knowledge and technology acquired through external search, many firms aim to improve and make radical changes to their existing products and/or services. Thus, we propose the following hypotheses:

Hypotheses 1a. The breadth of external search has a positive effect on a firm's exploratory innovation.

Hypotheses $\mathbf{1 b}$. The breadth of external search has a positive effect on a firm's exploitative innovation.

Hypotheses 2a. The depth of external search has a positive effect on a firm's exploratory innovation.

Hypotheses $\mathbf{2 b}$. The depth of external search has a positive effect on a firm's exploitative innovation.

\subsection{The Openness of Firms' External Search Strategies and Innovation Capability}

Whether the openness of firms' external search strategies is effective depends on the firm's several internal determinants, such as top management team (TMT) composition, whether or not the firm has a clear written vision [40], organizational structure (mechanistic or organic), improvisation and autonomy, path dependence, and routinization [54,55], as well as learning capabilities [36,56]. In our paper, we focus on innovation capability, which is a kind of learning capability targeting 
exploratory and exploitative innovation. The wider the breadth of external search, the greater the number of external sources of cooperation. Therefore, increasing the breadth of the external search will bring more innovation awareness, innovative knowledge, and innovative technology to a firm. This will promote the firm to achieve technological advancement, gain access to new markets, and upgrade its innovation capability. Speaking more precisely, a wider breadth of external search brings a firm more innovation consciousness and a stronger ability to have variation perception and screen the environment. The firm's decision-making capability can be strengthened through the search-learn-exchange information process across different organizational units and external parties [27], and then its implementation capability is enforced through taking actions for achieving innovation objectives.

The impact of the depth of the external search on innovation capability focuses on the absorption, utilization, and control of external technology/knowledge. First, a greater depth of external search means that a firm establishes and maintains good exchanges and cooperative relationships with other innovative entities to ensure the reliability and stability of their external technical knowledge sources [26]. It increases the awareness of a firm about technical information and knowledge and helps the firm interpret the information/knowledge correctly. Second, a greater depth of external search signifies the need for in-depth exchanges and cooperation between a firm and other technology entities that will reduce opportunistic behaviors during the cooperation and ensure the efficiency and reliability of technological knowledge transfer. It is useful for a firm to select its future innovation actions or innovation orientation based on cooperation arising from various interactions. Third, a greater depth of external search signifies that a firm realizes the absorption and utilization of external innovation resources under deeper innovation links [2,9], which requires a greater ability to integrate technology/knowledge and conduct innovation. This pushes the firm to strengthen its implementation capability to take actions for achieving innovation objectives. We can see that the depth of external search will influence the efficiency of a firm in the use of external resources, thus affecting its innovation capability. Therefore, we propose the following hypotheses:

Hypotheses 3a. The breadth of external search has a positive impact on a firm's innovation capability.

Hypotheses $\mathbf{3 b}$. The depth of external search has a positive impact on a firm's innovation capability.

\subsection{Innovation Capability and Types of Innovation}

The capability of firms to innovate plays a role in promoting exploitative and exploratory activities. The changing environment of competition, customer needs, and technological opportunities provides firms with more development opportunities, which encourages firms to use innovation capability to acquire external environmental information and combine historical trajectories to determine the development trends of the industry and, finally, form the development goals of the firm [57]. Exploitative and exploratory activities are both characteristics of innovation $[55,58]$, originated from the same root [20,59], and are highly related to innovation capability. The dynamic capability of a firm to explore new possibilities to create new products and/or services is related to exploratory innovation, whereas the dynamic capability of a firm to leverage old certainties to produce incremental products and/or services is related to exploitative innovation [35]. Therefore, innovation capability is not limited to a capability to use internal learning mechanisms to expand the breadth and depth of knowledge, as well as enhance the research and development capabilities and market capabilities of internal members of the organization, and thus ameliorate the existing products or services. It also includes the capability to integrate and reset internal and external resources to develop new products or services or promote the implementation of product development activities and commercialization activities based on the effective combination of new knowledge and existing products. Thus, innovation capability is a set of capabilities or a meta-capability [60].

Innovation capability enables a firm to monitor, collect, and deal with internal and external information and knowledge [33,61]; to identify business opportunities; to evaluate the real or 
potential business value of dynamic or variable information, determining what is possible and achievable; to create more business opportunities; and to implement more innovation and thus have a greater entrepreneurial spirit to choose a higher and more risky innovation type, namely exploratory innovation [13]. Exploratory innovation emphasizes the long-term competitiveness of firms. Valuable, scarce, difficult to imitate, and difficult to replace resources are the source of competitive advantages. In the case of limited capacity or high acquisition costs, firms can cooperate to achieve resource sharing and knowledge creation through external network cooperation, thereby increasing the added value of products and maximizing the resource efficiency of firms. If firms focus on existing resources and capabilities, they have a certain rigidity and inertia. The innovation capabilities enable them to change and reorganize the existing knowledge structures and organizational practices of the firms according to internal and external environmental changes, realize the ability to optimize matching of various elements, conduct exploitative innovation, improve products or processes, and adapt to changes in the environment. They often do not want to take risks to carry out greater innovation and prefer exploitative innovation. Therefore, we propose the following hypotheses:

Hypotheses 4a. Innovation capability has a significant positive impact on exploratory innovation.

Hypotheses $4 \mathbf{b}$. Innovation capability has a significant positive impact on exploitative innovation.

On the basis of the preceding literature review, we propose our conceptual research model as follows (see Figure 1).

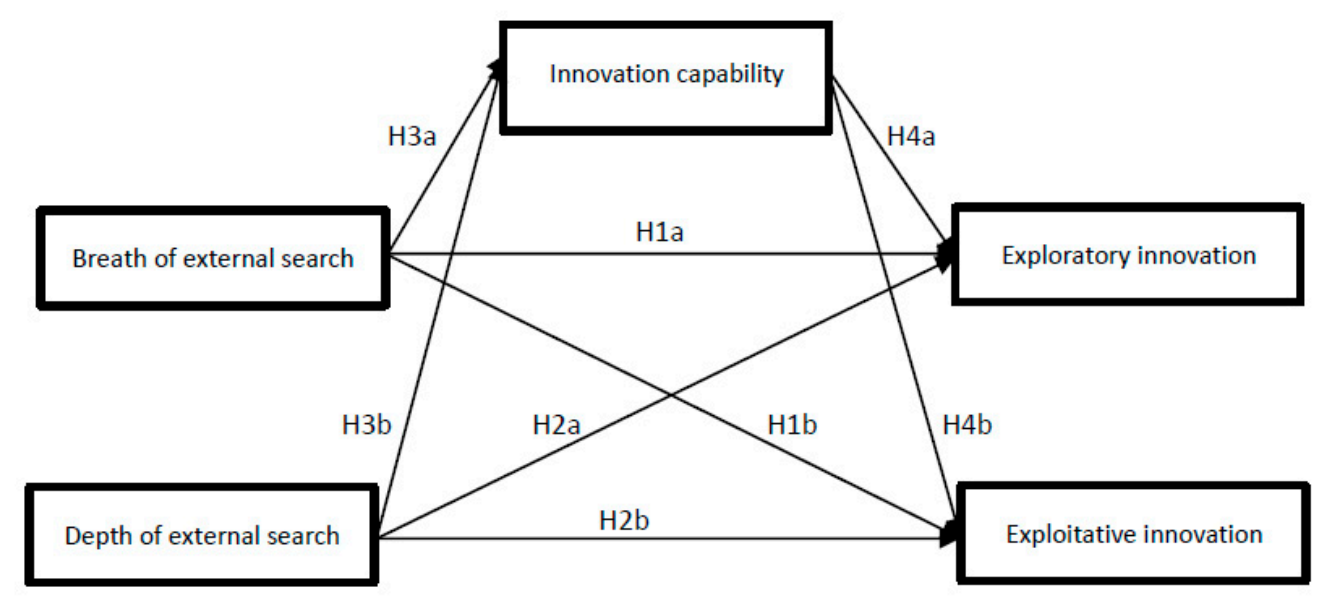

Figure 1. Conceptual research model.

\section{Research Methods}

\subsection{Data Collection}

Surveys are widely used in the research of organizational behavior and psychology fields because of their advantages, including saving time and labor, easier quantification of results, applicable for large-scale investigations, and easier analysis of results. In this study, we used a survey to collect data from Chinese manufacturing firms. In order to obtain reliable, first-hand data, we obtained help from the science and technology bureau of the local government in Jiangsu Province. The bureau required the top management of each manufacturing firm to complete the survey after an official meeting. Meanwhile, we went to a high-tech development zone in Sichuan Province, as well as in Shandong Province, where we used a one-on-one approach to survey manufacturing firms. We also obtained help from a bank's top management in Liaoning Province to collect data. Over a six-month period, we delivered a total of 134 questionnaires-from which 112 valid responses were received $(83.6 \%$ of the total questionnaires). The majority of these firms were located in Beijing, Liaoning, Jiangsu, Shandong, and Sichuan (89\%). All data were analyzed using SPSS19 and AMOS24. 


\subsection{Questionnaire Design and Scale Development}

The questionnaire had two parts. The first part included the firm profile: firm name, firm location, foundation year, number of employees, nature of the ownership, and industry. On the basis of the firm location, we categorize the surveyed firms into three regions: Eastern region, Central region, and Western region. Firm age is measured by the number of years after its founding, whereas the number of employees measured the firm size. The firm ownership is measured by four categories: state-owned enterprise, private enterprise, joint venture, and others. Following the OECD's industry classification [60], the sample firms are grouped into low-tech industries, medium-high-tech industries, and high-tech industries. These variables are considered as control variables in our study [62]. The second part of the survey included items for measuring the core variables of the study: the breadth of external search, the depth of external search, innovation capability, exploitative innovation, and exploratory innovation. The characteristics of the sampled firms are shown in Table 1.

Table 1. Characteristics of sample firms.

\begin{tabular}{cccc}
\hline Characteristic & Category & Frequency & Percentage (\%) \\
\hline \multirow{3}{*}{ Region } & Eastern Region & 43 & 38.39 \\
& Central Region & 4 & 3.57 \\
& Western Region & 65 & 58.04 \\
\hline \multirow{3}{*}{ Firm age } & Less than 5 years & 41 & 36.61 \\
& 6-10 years & 24 & 21.43 \\
& $11-20$ years & 26 & 23.21 \\
& More than 20 years & 21 & 18.75 \\
\hline \multirow{3}{*}{ Firm size } & Less than 100 people & 61 & 54.47 \\
& $101-300$ people & 15 & 13.39 \\
& 301-500 people & 7 & 6.25 \\
& 500-1000 people & 5 & 4.46 \\
& More than 1000 people & 24 & 21.43 \\
\hline \multirow{2}{*}{ Firm ownership } & Ptate-owned (holding) enterprise & 51 & 45.54 \\
& Private enterprise & 43 & 38.39 \\
& Joint venture & 6 & 5.36 \\
& Other & 12 & 10.71 \\
\hline \multirow{2}{*}{ Industry } & Low-technology industries & 6 & 5.36 \\
& Medium-high-technology industries & 87 & 77.68 \\
& High-technology industries & 19 & 16.96 \\
\hline
\end{tabular}

Following Laursen and Salter [10], we categorized innovation openness into the depth of external search and the breadth of external search. The depth of innovation openness was measured by the degree of cooperation with inside and outside sources of innovation. Customers, suppliers, competitors, universities/public research institutes, technology intermediaries, government bureaus of science and technology, venture capital institutions, and consulting service companies were viewed as a firm's external sources of innovation. Internal non-R \& D department staff, non-R \& D departments, and member firms in the company group were viewed as a firm's internal sources of innovation. We used five-point Likert scales to measure the depth of external search.

The breadth of external search was measured by the total number of innovation cooperation partners. We added a " 0 " to a five-point Likert scale. If a firm chose " 0 " for a certain source of innovation, it signified that the firm did not use the source to perform open innovation. This source was then removed from the 11 sources of innovation for that firm. The final number of sources indicated the extent of a firm's innovation breadth.

We used the scale from the work of [13] to measure innovation capability [21]. Their measurement scale was based on cognitive and behavioral perspectives and adopted grassroots theory to categorize innovation capability into the following: variability awareness capability, information interpretation 
ability, innovation decision-making capability, and implementation capability. The scale included 15 items, represented by IC1, IC2, IC3, ..., IC15 (see Table 3). We used seven-point Likert scales to measure the items.

For exploitative innovation and exploratory innovation, we used the scale developed by Jansen in 2006 [63], in which exploratory innovation was measured by six items (denoted as ETORY1, ETORY2, ETORY3, ..., ETORY6 in the current study). These items were stated as: “We are constantly creating new products and services"; "We often test new products and services in the local market"; "Even if it is a brand-new product and service for our company, we also want to bring it to market and commercialize it"; "We often use new business opportunities in new markets"; "Our unit regularly expands new sales channels"; and "We regularly find and approach new customers in new markets". Another six items were used to measure exploitative innovation (denoted as ETIVE1, ETIVE2, ETIVE3, ..., ETIVE6). They were as follows: "We often refine the supply of the company's existing products and services"; "We regularly make small improvements to existing products and services"; "We provide improved products and services for the local market"; "We continuously improve the supply efficiency of products and services"; "We obtain economies of scale in the existing market (by increasing sales scale and reducing costs)"; and "We will provide more services for existing customers" (see Table 3).

\section{Research Results}

\subsection{Descriptive Analysis}

Before analyzing the influence of external search on innovation types, we first conducted a correlation analysis among the variables (see Table 2).

\subsection{Reliability and Validity Test of the Scale}

We tested the reliability and validity of the identified scale (see Table 3). From Table 3, we can see that the Cronbach's $\alpha$ coefficient of each variable (values between 0.922 and 0.960 ) and the composite reliabilities (CR) (values between 0.939 and 0.961) all exceeded a threshold of 0.700 . The average variance extracted (AVE) values were all above 0.5 . This indicates that the measurement scales had good reliability. The Kaiser-Meyer-Olkin (KMO) values $(0.943,0.858$, and 0.929$)$ were greater than 0.700 , supporting that the sampling was adequate for the model and its associated variables. Further, the scales in our paper have been used by domestic and foreign scholars; their validity has been previously established. The first-order confirmatory factor analysis of the latent variables is detailed in Table 3. The results show that the latent variables had standardized factor loading coefficients between 0.701 and 0.968 . This signifies that the aggregate validity of the latent variables was acceptable. At the same time, we compared the square root of AVE with the correlation coefficient at the corresponding row and column, and we found that the former was always larger than the latter. Thus, the scales used in our paper had sufficient discriminant validity. 
Table 2. Descriptive analysis.

\begin{tabular}{|c|c|c|c|c|c|c|c|c|c|c|}
\hline & 1 & 2 & 3 & 4 & 5 & 6 & 7 & 8 & 9 & 10 \\
\hline 1. Region & 1 & & & & & & & & & \\
\hline 2. Firm Age & $-0.411^{* *}$ & 1 & & & & & & & & \\
\hline 3. Firm Size & -0.077 & $0.552 * *$ & 1 & & & & & & & \\
\hline 4. Ownership & $-0.272^{* *}$ & -0.107 & -0.183 & 1 & & & & & & \\
\hline 5. Industry & 0.136 & -0.101 & 0.105 & -0.001 & 1 & & & & & \\
\hline 6. External search breadth & -0.052 & -0.103 & -0.075 & -0.064 & -0.015 & 1 & & & & \\
\hline 7. External search depth & 0.040 & -0.102 & -0.023 & 0.026 & -0.055 & $0.600 * *$ & 1 & & & \\
\hline 8. Innovation capability & 0.037 & -0.110 & -0.047 & 0.142 & $-0.232 *$ & 0.11 & $0.421^{* *}$ & 1 & & \\
\hline 9. Exploitative innovation & 0.026 & -0.100 & -0.029 & 0.105 & -0.152 & -0.026 & $0.303^{* *}$ & $0.817^{* *}$ & 1 & \\
\hline 10. Exploratory innovation & 0.108 & $-0.225^{*}$ & -0.098 & 0.124 & -0.131 & 0.029 & $0.305^{* *}$ & $0.807^{* *}$ & $0.894^{* *}$ & 1 \\
\hline Mean & 2.196 & 2.241 & 2.25 & 1.813 & 1.902 & 10.643 & 3.725 & 5.33 & 5.378 & 5.462 \\
\hline S.D. & 0.966 & 1.141 & 1.636 & 0.954 & 1.039 & 1.106 & 0.677 & 0.839 & 0.959 & 0.879 \\
\hline
\end{tabular}

*: Significant correction is made at the 0.05 level; **: Significant correlation is made at the 0.01 level (both sides); the correlation coefficient values are shown at the lower left of the correlation coefficient matrix. 
Table 3. Rreliability and validity analysis.

\begin{tabular}{|c|c|c|}
\hline Variable & Construct and Meaning Items & SFL \\
\hline \multicolumn{3}{|c|}{ Innovation capability: $\alpha=0.929 ; \mathrm{AVE}=0.829 ; \mathrm{CR}=0.950 ; \mathrm{KMO}=0.943$} \\
\hline IC1 & $\begin{array}{l}\text { Our marketing staff communicates extensively with customers and obtains } \\
\text { customer information in a timely manner. }\end{array}$ & 0.89 \\
\hline IC2 & We are concerned about changes in customer needs. & 0.916 \\
\hline IC3 & $\begin{array}{l}\text { Our company has a dedicated market research department responsible for the } \\
\text { collection of market and customer demand change information. }\end{array}$ & 0.924 \\
\hline IC4 & We often invite external technical experts to conduct seminars. & 0.835 \\
\hline IC5 & We often invite industry-leading market analysts to companies to discuss topics. & 0.804 \\
\hline IC6 & $\begin{array}{l}\text { Our professionals (technical, marketing staff, and so on) often participate in } \\
\text { various external related conferences, forums, and seminars. }\end{array}$ & 0.801 \\
\hline IC7 & $\begin{array}{l}\text { In the process of formulating an innovation strategy, we base our choice of options } \\
\text { on multiple member perspectives. }\end{array}$ & 0.775 \\
\hline IC8 & $\begin{array}{l}\text { In the process of formulating an innovation strategy, we produce as many } \\
\text { scenarios as possible from multiple perspectives. }\end{array}$ & 0.794 \\
\hline IC9 & $\begin{array}{l}\text { We will conduct a comprehensive inspection of the plan to improve } \\
\text { decision-making. }\end{array}$ & 0.946 \\
\hline IC10 & $\begin{array}{l}\text { In the process of formulating the innovation strategy, we chose the program based } \\
\text { on multi-angle evaluation. }\end{array}$ & 0.965 \\
\hline IC11 & $\begin{array}{l}\text { During the implementation process, we made recommendations based on the } \\
\text { assessment status and adjusted the work in time. }\end{array}$ & 0.908 \\
\hline IC12 & We regularly evaluate the resource use of innovative projects. & 0.892 \\
\hline IC13 & $\begin{array}{l}\text { Regular meetings between our departments discuss technology and market trends } \\
\text { for corrections and adjustments. }\end{array}$ & 0.852 \\
\hline IC14 & $\begin{array}{l}\text { It is easier for our company to obtain the resources needed for innovation from the } \\
\text { outside than inside. }\end{array}$ & 0.776 \\
\hline IC15 & $\begin{array}{l}\text { Our managers often discuss relevant policies, laws, regulations, competitors, and } \\
\text { possible outcomes for timely adjustments. }\end{array}$ & 0.861 \\
\hline \multicolumn{3}{|c|}{ Exploratory innovation: $\alpha=0.945 ; \mathrm{AVE}=0.721 ; \mathrm{CR}=0.939 ; \mathrm{KMO}=0.858$} \\
\hline ETORY1 & We are constantly creating new products and services. & 0.967 \\
\hline ETORY2 & We often test new products and services in the local market. & 0.895 \\
\hline ETORY3 & $\begin{array}{l}\text { Even if it is a brand-new product and service for our company, we also want to } \\
\text { bring it to market and commercialize it. }\end{array}$ & 0.872 \\
\hline ETORY4 & We often use new business opportunities in new markets. & 0.881 \\
\hline ETORY5 & Our unit regularly expands new sales channels. & 0.750 \\
\hline ETORY6 & We regularly find and approach new customers in new markets. & 0.701 \\
\hline \multicolumn{3}{|c|}{ Exploitative innovation: $\alpha=0.960 ; \mathrm{AVE}=0.803 ; \mathrm{CR}=0.961 ; \mathrm{KMO}=0.929$} \\
\hline ETIVE1 & We often refine the supply of the company's existing products and services. & 0.918 \\
\hline ETIVE2 & We regularly make small improvements to existing products and services. & 0.894 \\
\hline ETIVE3 & We provide improved products and services for the local market. & 0.894 \\
\hline ETIVE4 & We continuously improve the supply efficiency of products and services. & 0.911 \\
\hline ETIVE5 & $\begin{array}{l}\text { We obtain economies of scale in the existing market (by increasing sales scale and } \\
\text { reducing costs). }\end{array}$ & 0.883 \\
\hline ETIVE6 & We will provide more services for existing customers. & 0.876 \\
\hline
\end{tabular}




\subsection{Collinearity Tests and Hypothesis Test Results}

Before we tested the hypotheses, we used SPSS19 and STATA to make heteroscedasticity and residual normality tests. Our test results show that there is no heteroscedasticity and the normal distribution is respected (see Appendix A: Figure A1, Tables A1 and A2, Figure A2). And then, we explored collinearity issues and potential autocorrelation [62]. When considering collinearity, we conducted multicollinearity tests $[33,61]$, essentially meaning that all control variables and independent variables were put into the model and the tolerance and variance inflation factor (VIF) of each variable was analyzed. The Durbin-Watson (DW) method was also adopted to test the sample data for residual independence. The analysis results (see Table 4) show that the tolerance of all variables ranges from 0.636 to 0.956 , and the maximum VIF within the models was 1.573 , which is much lower than 10. Thus, it is unlikely to have the multicollinearity problem in this study [64]. These results suggest that a regression analysis is suitable. The DW value is around 2 (1.828 and 2.045); thus, it does not influence the accuracy of the t-test and F-test results.

Then, on the basis of our conceptual research model, a hierarchical multivariate regression method was adopted. Control variables (region, firm age, firm size, nature of firm, and industry), independent variables (external search breath and external search depth), and a mediator variable (innovation capability) were gradually added to the model for analysis. Model 1 and Model 5 only considered the control variables; Model 2 and Model 6 added the external search breadth; Model 3 and Model 7 added external search depth; Model 4 and Model 8 added innovation capability; and Model 9 and Model 10 added the interactions among the control variables, independent variables, and the mediating variablee (see Table 4).

Table 4 shows the results of the multiple linear regressions. In Model 1, industry had a positive and significant impact on exploratory innovation, whereas other control variables had no such impact. Once external search breadth added in Model 2 and Model 6, and the $\mathrm{R}^{2}$ had very little change, namely 0.121 and 0.153 , respectively. However, when external search depth was added in Model 3 and Model 7, the $R^{2}$ jumped to 0.168 and 0.202 , respectively. Further, when innovation capability was added in Model 4 and Model 8, the $\mathrm{R}^{2}$ increased to 0.688 and 0.686 , respectively. The parameter estimation shows that external search depth and innovation capability have a significant positive effect on exploratory innovation and exploitative innovation. In Model 2, external search breadth had no significant positive impact on exploratory innovation, thus Hypotheses 1a as not supported. This may be because cooperation with too many sources of innovation can enable firms to acquire more innovative knowledge and information, but firms may not have the ability to digest and absorb knowledge and information to form their own innovation capabilities, which will not enhance the firm's exploratory innovation. In Model 3, external search depth had a significant positive impact on exploratory innovation $(\beta=0.282, p<0.05)$, thus Hypotheses $2 a$ was verified. It signifies that the in-depth cooperation with external innovation sources enhanced the firm's exploratory innovation. To make this exploratory innovation successful, it needs a flexible organizational structure, an easy mobility of knowledge-based employees, employee empowerment, and a creation environment. These internal factors can help the firm to identify new business opportunity, create new products/services, find and approach new customers in new markets, expand new sales channels, and so on. In Model 4, when the innovation capability variable was added, the impact of external search depth on exploratory innovation became insignificant. Innovation capability significantly affects exploratory innovation ( $\beta=0.850, p<0.001)$, which indicates that innovation capability played a full intermediary role in the relationship between external search depth and exploratory innovation. Hypothesis 4a was supported. The in-depth of external innovation searches improves the firm's internal innovation capability, strengthening mutual trust and interest. Famous Chinese companies like Huawei, ZTE, Lenovo, and Tecent all actively engage in external innovation searches. Their high-level innovation capability and great exploratory innovation cannot separate from the in-depth external search strategy. 
Table 4. Regression model analysis.

\begin{tabular}{|c|c|c|c|c|c|c|c|c|c|c|}
\hline \multirow{3}{*}{ Variables } & \multicolumn{8}{|c|}{ Dependent Variables } & \multirow{2}{*}{\multicolumn{2}{|c|}{$\begin{array}{c}\text { Mediating Variable } \\
\text { Innovation Capability }\end{array}$}} \\
\hline & \multicolumn{4}{|c|}{ Exploratory Innovation } & \multicolumn{4}{|c|}{ Exploitative Innovation } & & \\
\hline & Model 1 & Model 2 & Model 3 & Model 4 & Model 5 & Model 6 & Model 7 & Model 8 & Model 9 & Model 10 \\
\hline Region & -0.11 & -0.067 & -0.115 & -0.107 & -0.013 & -0.012 & -0.018 & -0.011 & 0.014 & -0.008 \\
\hline Age & -0.112 & -0.111 & -0.092 & -0.015 & -0.21 & -0.215 & -0.193 & -0.125 & -0.104 & -0.083 \\
\hline Size & 0.032 & 0.022 & 0.027 & 0.006 & 0.045 & 0.04 & 0.04 & 0.022 & 0.033 & 0.022 \\
\hline Ownership & 0.151 & 0.111 & 0.122 & -0.013 & 0.151 & 0.124 & 0.126 & 0.007 & 0.188 & 0.144 \\
\hline Industry & $0.656^{* *}$ & $0.331^{* *}$ & $0.547^{* *}$ & $0.293 *$ & $0.59^{* *}$ & $0.315^{* *}$ & $0.494^{* *}$ & $0.269 *$ & $0.399 *$ & $0.272 *$ \\
\hline ESB & & 0.089 & & & & 0.035 & & & 0.054 & \\
\hline ESD & & & $0.375^{*}$ & -0.112 & & & $0.333 *$ & -0.097 & & $0.521^{* * *}$ \\
\hline IC & & & & $0.934^{* * *}$ & & & & $0.826^{* * *}$ & & \\
\hline$R^{2}$ & 0.113 & 0.121 & 0.168 & 0.688 & 0.151 & 0.153 & 0.202 & 0.686 & 0.091 & 0.222 \\
\hline$\Delta \mathrm{R}^{2}$ & 0.113 & 0.08 & 0.054 & 0.52 & 0.151 & 0.002 & 0.051 & 0.484 & 0.091 & 0.222 \\
\hline $\mathrm{F}$ & 2.711 & 2.407 & 3.525 & 32.734 & 3.784 & 3.151 & 4.439 & 32.481 & 1.747 & 5.008 \\
\hline Tolerance & $0.642-0.956$ & $0.639-0.952$ & $0.64-0.941$ & $0.636-0.889$ & $0.642-0.956$ & $0.636-0.952$ & $0.64-0.941$ & $0.636-0.889$ & $0.691-0.952$ & $0.64-0.941$ \\
\hline VIF & $1.046-1.559$ & $1.081-1.566$ & $1.063-1.564$ & $1.125-1.573$ & $1.125-1.573$ & $1.05-1.565$ & $1.063-1.564$ & $1.125-1.537$ & $1.05-1.448$ & $1.063-1.564$ \\
\hline D.W. & & & & 1.827 & & & & 2.045 & & \\
\hline
\end{tabular}

${ }^{*} p<0.05,{ }^{* *} p<0.01,{ }^{* * *} p<0.001$. ESB $=$ external search breadth; ESD = external search depth; IC = innovation capability; DW = Durbin-Watson; VIF = variance inflation factor. 
In Model 5, other control variables had no significant effect on exploitative innovation, except industry. In Model 6, external search breadth had no significant positive impact on exploitative innovation, thus Hypotheses $1 \mathrm{~b}$ was not verified. This may be because, on the one hand, the number of external sources cannot bring in a firm's needed resources; on the other hand, firms cannot integrate and innovate the acquired knowledge and information. Therefore, they cannot promote exploitative innovation. In Model 7, external search depth had a significant positive impact on exploitative innovation $(\beta=0.271, p<0.05)$, thus Hypotheses $2 \mathrm{~b}$ was verified, which signifies that in-depth cooperation with external sources can enhance the firm's exploitative innovation. The exploitative innovation is usually in line with hierarchical structure, lock-in trajectory, and stabilization culture. These internal factors influence the firm to improve existing products/services, improve the supply efficiency of products/services, obtain economies of scale in the existing market, provide more products/services to existing customers, and so on. In Model 8, when the innovation capability variable was added, the impact of external search depth on exploitative innovation became insignificant, and the innovation capability significantly affected exploitative innovation $(\beta=0.824, p<0.001)$, indicating that innovation capability played a full intermediary role between external search depth and exploitative innovation. Hypotheses $4 \mathrm{~b}$ was supported. Even though the significant level of innovation capacity in model 8 is slightly lower than that in Model $4(\beta=0.850, p<0.001)$, it confirms again the importance of innovation capacity. This indicates that both exploitative innovation and exploratory innovation needs the corresponding innovation capacity. For exploratory innovation, it requires even higher level of innovation capability.

In Model 9, the breadth of external search had a positive, but not significant impact on innovation capability. This may be because the external search breadth did not bring in much of the firms' needed knowledge and resources to strengthen their innovation capability. The large number of external cooperation partners without mutual trust and deep resource exchange did not guarantee enough knowledge/technology transfer. Thus, Hypotheses 3a was refused. However, Model 10 shows that the external search depth had a significant positive effect on innovation capability ( $\beta=0.394, p<0.001$ ). Hypotheses $3 \mathrm{~b}$ was supported. This is because deep cooperation with external innovation resources enhances mutual understanding, trust, respect, and knowledge/technology exchanges, so as to improve innovation capability.

\section{Conclusions and Implications}

\subsection{Research Findings}

In the existing literature on external search and type of innovation, there is no unanimous conclusion on how-or even whether-external search influences the type of innovation. Furthermore, little literature uses a process innovation perspective to measure innovation capability. Our study collected reliable, first-hand data from 112 Chinese manufacturing firms and used innovation capability as a mediating variable to analyze how the depth and breadth of external search influences the type of innovation. On the basis of our empirical research results, we drew the following conclusions:

(1) The depth of external search was significantly and positively correlated with innovation capability and exploitative innovation. Innovation capability played a full intermediary role between external search depth and exploitative innovation;

(2) The depth of external search was significantly and positively correlated with innovation capability and exploratory innovation. Innovation capability has played a full intermediary role between external search depth and exploratory innovation;

(3) External search breadth had no significant impact on innovation type. Even though the external search brings more contact with external innovation sources, invaluable and/or little exchange of information, knowledge, and technology cannot promote either exploratory or exploitative innovation. A wide connection with external sources may make firms unable to effectively dig deep into the source 
of innovation and unable to concentrate resources to enhance their own capabilities so that firms fail to choose the proper type of innovation.

(4) Industry had a positive and significant impact on the innovation capability and innovation types. This outcome is in line with the results of Zawislak et al. [60] and Hatzichronoglou [65]. Firms engaging in high-tech industries and high-medium-tech industries have higher innovation capability and are more innovative than those in low-tech industries.

\subsection{Management Implications}

The above conclusions provide the following implications for manufacturing firms to consider in matching external search and innovation capability with innovation types:

(1) Researchers, business practitioners, and innovation policy-makers have reached an agreement that innovation is a key factor for a firm's sustainability and competitiveness. Different types of innovation have different effects on business performance. The environment in which companies run their business is dynamic and uncertain. Open innovation has become a trend for firms to conduct $R \& D$ activities. This requires companies to identify the depth and breadth of their open innovation and select appropriate types of innovation for sustainable development.

(2) Exploratory innovation enables companies to hold better competitive advantages compared with exploitative innovation. According to theories with a resource-based view, imitation and substitution can only bring rewards to innovative companies for maintaining a market balance, and major innovation can bring them competitive advantages and excellent financial returns. Export-oriented companies operating in an increasingly competitive environment should invest more resources into exploratory innovation for gaining a sustainable and competitive advantage.

(3) Although external search has a significant and positive impact on the type of innovation, it does not mean that a higher degree of openness is always better. The appropriate degree of openness enables companies to select a suitable type of innovation, which will promote innovation activities and foster core technological advantages. However, no matter which level of openness and what type of innovation, they are closely related to innovation capability. Firms should try their best to improve their innovation capability [66].

\section{Discussion}

Firms' exploitation and exploration has drawn scholars' attention in business, leadership, and entrepreneurship contexts in recent years $[59,67,68]$. By engaging in exploitation innovation, firms tried to refine the existing competences, technologies, products, processes, and services. Therefore, exploitative innovation is a way to help firms to improve the current products or services in order to satisfy more effectively the existing customers' demands. Despite having several benefits, focusing solely on exploitative innovation makes it hard for firms to adapt to the fast changes in the market and technology [69], which eventually may threaten the business performance. Furthermore, the consumers' needs and preferences are changing rapidly over time. The firms that focus exclusively on exploitative innovation may not be able to respond their customers' demands effectively [70].

Some firms engage more in exploratory innovation, because it helps them to differentiate their products and services from the competition [63]. The novel products, services, or business models as the result of exploratory innovation enable firms to go one step ahead of the rivals in the current market. Exploratory innovation enables firms to enter markets that are new to them, or to create new markets that do not yet exist at all. However, focusing exclusively on exploration innovation can exhaust the financial resources before the organizations can have benefits [69]. Therefore, some other firms in the same industry may prefer to balance exploitation and exploration activities in order to obtain a better competitive position compared with the direct competitors. In doing so, a specific unit of the company may devote more to exploration activities, while another unit deals with exploitation activities simultaneously. 
In this study, we sought to identify the internal factors of the firms' engagement in exploratory innovation versus exploitative innovation. In doing so, our study highlighted the important role of the openness of external search processes in the types of firms' innovation activities. In contrast with the work of [10], we found that the number of external search channels that a specific organization draws upon in its innovative activities (external search breath) is not an important factor for firms' innovation (both exploitation and exploration). Interestingly, our result confirmed that external search depth is crucial for enriching firms' innovation capability, which in turn enhances both exploitation innovation and exploration innovation. Accordingly, external search depth enables organizations to enrich its knowledgebase and information about different customers, technologies, competitors, and markets. The constant searching for such novel knowledge and information from outsiders enhances the awareness of firms about market opportunities that provide a foundation for firms to engage in exploitation and exploration innovation.

Further, our study provides a new insight to confirm that the industry has a positive and significant effect on innovation capability and innovation types under the openness of firms' external search strategies $[60,65]$. Firms engaging in high-tech industries and high-medium-technology industries have a higher innovation capability, which promotes generating greater exploratory and exploitative innovation. However, firm location, age, size, and ownership have been found to have no discernible impact on the capability and types of innovation. After over one decade of the implementation of "The Development of the West China" and "The Rise of Central China" strategies, the Central-Western regions have been upgrading their innovation capability and innovation types. The Eastern region is more export-oriented than the Central-Western regions and traditionally holds more advantages in human resources, capital, technology, openness, and geography. However, the region has suffered a lot from the financial crisis originated from the USA and the current trade war between the USA and China. Also, some big cities in the Central-Western regions, like Wuhan, Changsha, Chongqing, Chengdu, and $\mathrm{Xi}^{\prime}$ an, driven by the huge local economic potential, have been increasingly attracting the inflow of firms, talents, and capital. This is helping to decrease the innovation gap between the East and the Central -West. Both the East and the Central-West are improving innovation capability and can conduct the ambidexterity of exploratory and exploitative innovation. As for the firm age, it has a negative but insignificant effect on innovation capability and innovation types. This may be because older firms are less motived to conduct innovation than younger firms. They tend to follow routines, established procedures, and rules, which are related to exploitative innovation, but do not support exploratory innovation [63]. China launched a mass innovation and entrepreneurship initiative in 2014, which generated thousands of new ventures every year. Some of these new ventures have become unicorns, such as Cloudwalk (AI \& robotics), Caocao Zhuanche (transportation), Du Xiaoman (fintech), Hello Bike (sharing transportation), and Luckin Coffee (consumer upgrade). These young high-tech firms are an engine to bring in exploratory and exploitative innovation and improve society welfare. Similar to firm age, we found that firm size has a positive but insignificant effect on innovation capability and innovation types. This is consistent with the research findings in the existing literature [71,72]. More information about the effect of these control variables on innovation capability can be found in Appendix A Table A3.

\section{Limitations and Future Research}

Our study provides some contributions to the existing literature. Although it has some weaknesses, these shortcomings leave space for future research. For example, the number of manufacturing firms surveyed was limited to 112 . There was a lack of sample firms in medium-low-technology industries. Many of these firms were in the east coastal regions and western regions, and few were from the Middle-West. If there were more data from the three regions for balance, we could make a comparable study about the differences in external search, innovation capability, and innovation type between the regions. Future research needs to survey more firms (ideally, at least up to 200). Larger samples will make the research findings more robust. Furthermore, this study did not consider moderating variables. 
Future research can examine whether internal organizational characteristics (e.g., organizational structure, culture, and attention) and external environmental factors (e.g., government innovation policy, competitors, and demography) have a moderating effect on the relationship between external search and innovation type. Further, a comparison study between firms with external search strategies and firms without such strategies needs to be explored. Finally, our surveyed firms conduct business in different manufacturing sectors. Different sectors may prefer different types of innovation. Future research can examine the manufacturing sector, and verify whether the impact of external search on innovation type varies sector by sector.

Author Contributions: Conceptualization: M.T.; literature review: M.T., P.X., P.L., A.A.J.; methodology, data curation and validation: M.T. and P.X.; writing—original draft preparation: M.T., P.X., P.L., A.A.J.; writing-review and editing: M.T. and A.A.J.; project administration and funding acquisition: M.T.

Funding: We would like to acknowledge the financial support provided by the Sichuan Social Sciences Research Planning Bureau (grant number SC17TJ021), the National Natural Science Foundation of China (grant number G0302/71403221), and the Sichuan Science and Technology Bureau Soft Science Program (grant number 2017ZR0240).

Conflicts of Interest: The authors declare no conflict of interest.

\section{Appendix A}

(1) Heteroscedasticity Test

As we can see in Figure A1 the scatter diagram is evenly and horizontally distributed. Thus, there is no heteroscedasticity.
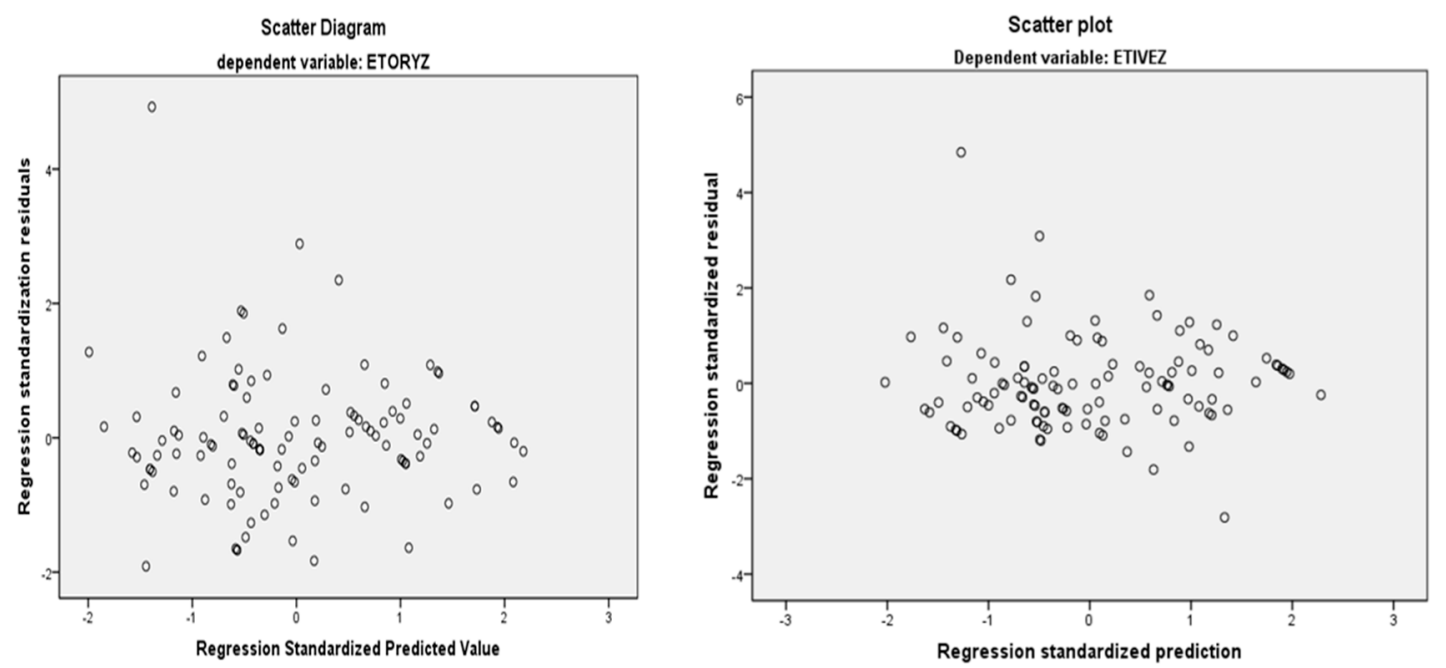

Figure A1. Heteroscedasticity test.

(2) Residual Normality Test

Tables A1 and A2 represent the results of residual normality tests.

Table A1. The result of the Kolmogorov-Smirnova (K-S) test when the dependent variable is exploratory innovation.

\begin{tabular}{ccccccc}
\hline & \multicolumn{3}{c}{ Kolmogorov-Smirnova } & \multicolumn{3}{c}{ Shapiro-Wilk } \\
\cline { 2 - 7 } & Statistics & df & Sig. & Statistics & df & Sig. \\
\hline Standardized Residual & 0.083 & 112 & 0.057 & 0.981 & 112 & 0.113 \\
\hline
\end{tabular}

Lilliefors significant level correction. 
Table A2. The result of the K-S test when the dependent variable is exploitative innovation.

\begin{tabular}{ccccccc}
\hline & \multicolumn{3}{c}{ Kolmogorov-Smirnova } & \multicolumn{3}{c}{ Shapiro-Wilk } \\
\cline { 2 - 7 } & Statistics & df & Sig. & Statistics & df & Sig. \\
\hline Standardized Residual & 0.083 & 112 & 0.067 & 0.974 & 112 & 0.131 \\
\hline & \multicolumn{4}{c}{ Lilliefors significant level correction. } & &
\end{tabular}

As shown in the Q-Q plot in Figure A2, these plots are basically distributed in the vicinity of the straight line. Thus, it can be considered as a normal distribution.
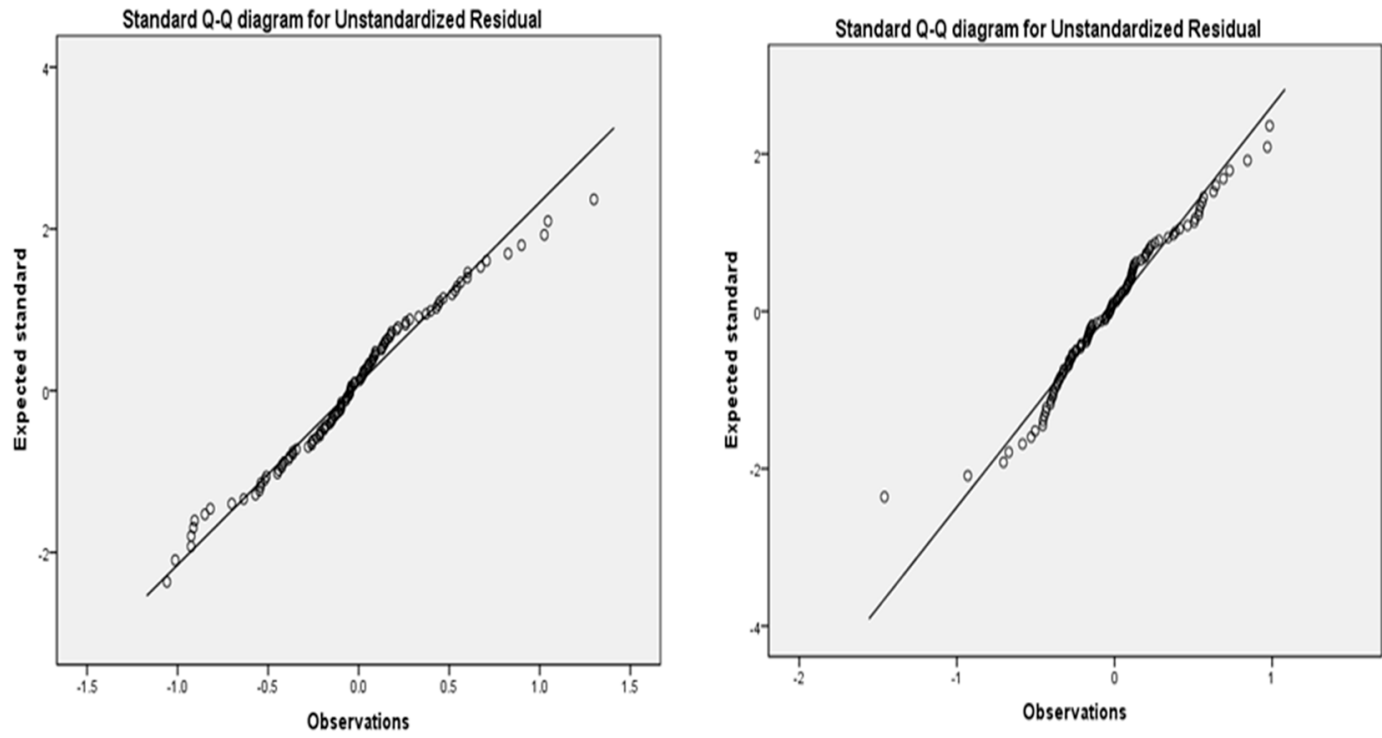

Figure A2. Residual normality test.

Table A3. The effect of control variables on innovation capability

\begin{tabular}{|c|c|c|c|c|}
\hline Control Variables & Item & Frequency & $\begin{array}{c}\text { Frequency } \\
(\%)\end{array}$ & $\begin{array}{c}\text { Innovation } \\
\text { Capability on } \\
\text { Average }\end{array}$ \\
\hline \multirow{3}{*}{ Region } & Eastern Region & 43 & 38.39 & 5.346923 \\
\hline & Central Region & 4 & 3.57 & 5.6 \\
\hline & Western Region & 65 & 58.04 & 5.27814 \\
\hline \multirow{4}{*}{ Year of foundation } & Less than 5 years & 41 & 36.61 & 5.467805 \\
\hline & 6-10 years & 24 & 21.43 & 5.293021 \\
\hline & $11-20$ years & 26 & 23.21 & 5.192212 \\
\hline & More than 20 years & 21 & 18.75 & 5.271429 \\
\hline \multirow{5}{*}{ Firm size } & Less than 100 people & 61 & 54.47 & 5.375984 \\
\hline & 101-300 people & 15 & 13.39 & 5.315167 \\
\hline & $301-500$ people & 7 & 6.25 & 5.007143 \\
\hline & 500-1000 people & 5 & 4.46 & 5.521 \\
\hline & More than 1000 people & 24 & 21.43 & 5.274688 \\
\hline \multirow{4}{*}{ Nature of business } & State-owned (holding) enterprise & 51 & 45.54 & 5.21299 \\
\hline & Private Enterprise & 43 & 38.39 & 5.404128 \\
\hline & Joint ventures & 6 & 5.36 & 5.13 \\
\hline & Other & 12 & 10.71 & 5.6575 \\
\hline \multirow{3}{*}{ Industry } & Low-technology industries & 6 & & 5.145417 \\
\hline & Medium-high-technology industries & 87 & & 5.243736 \\
\hline & High-technology industries & 19 & & 5.780658 \\
\hline
\end{tabular}




\section{References}

1. Truffer, B.; Coenen, L. Environmental Innovation and Sustainability Transitions in Regional Studies. Reg. Stud. 2012, 46, 1-21. [CrossRef]

2. Seebode, D.; Jeanrenaud, S.; Bessant, J. Managing innovation for sustainability. RD Manag. 2012, 42, $195-206$. [CrossRef]

3. Wagner, M. The links of sustainable competitiveness and innovation with openness and user integration: An empirical analysis. Int. J. Innov. Sustain. Dev. 2009, 4, 314. [CrossRef]

4. Brem, A.; Puente-Diaz, R.; Agogué, M. Creativity and innovation: State of the art and future perspectives for research. Int. J. Innov. Manag. 2016, 20, 1-12. [CrossRef]

5. Brem, A.; Voigt, K.-I. Integration of market pull and technology push in the corporate front end and innovation management-Insights from the German software industry. Technovation 2009, 29, 351-367. [CrossRef]

6. Trott, P.; Hartmann, D. Why “Open Innovation” is Old Wine in New Bottles. Int. J. Innov. Manag. 2009, 13, 715-736. [CrossRef]

7. Vanhaverbeke, W.; Van de Vrande, V.; Chesbrough, H. Understanding the Advantages of Open Innovation Practices in Corporate Venturing in Terms of Real Options. Creat. Innov. Manag. 2008, 17, 251-258. [CrossRef]

8. Chesbrough, H. Open Business Models: How to Thrive in the New Innovation Landscape, 1st ed.; Harvard Business School Press: Boston, MA, USA, 2006.

9. Koski, H.; Svento, R. Complementarity of firms' innovation strategies: Knowledge search, in-house R\&D and external R\&D acquisition. Int. J. Technol. Transf. Commer. 2017, 14,1-15. [CrossRef]

10. Laursen, K.; Salter, A. Open for innovation: The role of openness in explaining innovation performance among U.K. manufacturing firms. Strateg. Manag. J. 2006, 27, 131-150. [CrossRef]

11. Yun, J.J. Open Innovation: Technology, Market and Complexity in South Korea. Sci. Technol. Soc. 2016, 21, 319-323. [CrossRef]

12. Afshar Jahanshahi, A. Disentangling the emergence of perceived environmental uncertainty among technology entrepreneurs. Kybernetes 2016, 45, 962-976. [CrossRef]

13. Zhang, J.; Ziegler, M.; Zhang, J.; Ziegler, M. Interaction Effects between Openness and Fluid Intelligence Predicting Scholastic Performance. J. Intell. 2015, 3, 91-110. [CrossRef]

14. Yang, Y.; Wang, Q.; Zhu, H.; Wu, G. What Are the Effective Strategic Orientations for New Product Success under Different Environments? An Empirical Study of Chinese Businesses. J. Prod. Innov. Manag. 2012, 29, 166-179. [CrossRef]

15. Walsh, P.R. Innovation Nirvana or Innovation Wasteland? Identifying commercialization strategies for small and medium renewable energy enterprises. Technovation 2012, 32, 32-42. [CrossRef]

16. Mihalache, O.R.; Jansen, J.J.P.; Van den Bosch, F.A.J.; Volberda, H.W. Top management team shared leadership and organizational ambidexterity: A moderated mediation framework. Strateg. Entrep. J. 2014, 8, 128-148. [CrossRef]

17. Lubatkin, M.H.; Simsek, Z.; Ling, Y.; Veiga, J.F. Ambidexterity and performance in small-to medium-sized firms: The pivotal role of top management team behavioral integration. J. Manag. 2006, 32, 646-672. [CrossRef]

18. Heavey, C.; Simsek, Z.; Fox, B.C. Managerial Social Networks and Ambidexterity of SMEs: The Moderating Role of a Proactive Commitment to Innovation. Hum. Resour. Manag. 2015. [CrossRef]

19. Voss, G.B.; Voss, Z.G. Strategic Ambidexterity in Small and Medium-Sized Enterprises: Implementing Exploration and Exploitation in Product and Market Domains. Organ. Sci. 2013, 24, 1459-1477. [CrossRef]

20. Benner, M.J.; Tushman, M. Process Management and Technological Innovation: A Longitudinal Study of the Photography and Paint Industries. Adm. Sci. Q. 2002, 47, 676. [CrossRef]

21. O'Reilly, C.A.; Tushman, M.L. Ambidexterity as a dynamic capability: Resolving the innovator's dilemma. Res. Organ. Behav. 2008, 28, 185-206. [CrossRef]

22. Laursen, K.; Salter, A. Searching high and low: What types of firms use universities as a source of innovation? Res. Policy 2004, 33, 1201-1215. [CrossRef]

23. Keupp, M.M.; Gassmann, O. Determinants and archetype users of open innovation. RED Manag. 2009, 39, 331-341. [CrossRef]

24. Chen, Y.; Chen, J. Open Innovation: Mechanism and Model. Beijing Sci. Press 2008, 4, 1-9. 
25. Chun, Y.; Cai, N. Mechanism of impact of innovation openness on open innovation performance. Sci. Res. Manag. 2014, 35, 18-24. [CrossRef]

26. Yufen, C.; Jin, C. A study on the mechanism of open innovation promoting innovative performance. Sci. Res. Manag. 2009, 4, 1-9.

27. Winter, S.G. The Satisficing Principle in Capability Learning. Strateg. Manag. J. 2000, 21, 981-996. [CrossRef]

28. Wei, F.; Feng, N.; Zhang, K.; Wei, F.; Feng, N.; Zhang, K.H. Innovation Capability and Innovation Talents: Evidence from China Based on a Quantile Regression Approach. Sustainability 2017, 9, 1218. [CrossRef]

29. Lane, P.J.; Lubatkin, M. Relative absorptive capacity and interorganizational learning. Strateg. Manag. J. 1998, 19, 461-477. [CrossRef]

30. Szeto, E. Innovation capacity: Working towards a mechanism for improving innovation within an inter-organizational network. TQM Mag. 2000, 12, 149-158. [CrossRef]

31. Jahanshahi, A.A.; Zhang, S.X. Real Options Reasoning and Innovative Performance in the Context of Dynamic Capabilities. In Adoption of Innovation; Brem, A., Viardot, É., Eds.; Springer International Publishing: Cham, Switzland, 2015; ISBN 978-3-319-14522-8.

32. Jahanshahi, A.A.; Brem, A. Sustainability in SMEs: Top Management Teams Behavioral Integration as Source of Innovativeness. Sustainability 2017, 9, 1899-1915. [CrossRef]

33. Nawaser, K.; Jahanshahi, A.A. The antecedents of firm innovativeness: Empirical evidence from small-sized firms. Middle East J. Manag. 2018, 5, 105. [CrossRef]

34. Zahra, S.A.; George, G. Absorptive Capacity: A Review, Reconceptualization, and Extension. Acad. Manag. Rev. 2002, 27, 185-203. [CrossRef]

35. Limaj, E.; Bernroider, E.W.N. The roles of absorptive capacity and cultural balance for exploratory and exploitative innovation in SMEs. J. Bus. Res. 2019, 94, 137-153. [CrossRef]

36. Floyd, S.W.; Lane, P.J. Strategizing Throughout the Organization: Managing Role Conflict in Strategic Renewal. Acad. Manag. Rev. 2000, 25, 154-177. [CrossRef]

37. Hung, K.-P.; Chou, C. The Impact of Open Innovation on Firm Performance: The Moderating Effects of Internal R\&D and Environmental Turbulence. Technovation 2013, 33, 368-380. [CrossRef]

38. Lai, H.-C.; Weng, C.S. Exploratory innovation and exploitative innovation in the phase of technological discontinuity: The perspective on patent data for two IC foundries. Asian J. Technol. Innov. 2016, 24, 41-54. [CrossRef]

39. Greve, H.R. “Exploration and exploitation in product innovation". Ind. Corp. Chang. 2007, 16, 945-975. [CrossRef]

40. Koryak, O.; Lockett, A.; Hayton, J.; Nicolaou, N.; Mole, K. Disentangling the antecedents of ambidexterity: Exploration and exploitation. Res. Policy 2018, 47, 413-427. [CrossRef]

41. March, J.G. Exploration and exploitation in organizational learning. Organ. Sci. 1991, 2, 71-87. [CrossRef]

42. Stettner, U.; Lavie, D. Ambidexterity under scrutiny: Exploration and exploitation via internal organization, alliances, and acquisitions. Strateg. Manag. J. 2014, 35, 1903-1929. [CrossRef]

43. Brown, S.; Eisenhardt, K. The art of continuous change: Linking complexity theory and time-paced evolution in relentlessly shifting organizations. Adm. Sci. Q. 1997, 42, 1-34. [CrossRef]

44. Lavie, D.; Rosenkopf, L. Balancing Exploration And Exploitation In Alliance Formation. Acad. Manag. J. 2006, 49, 797-818. [CrossRef]

45. Lin, C.; Chang, C.-C. A patent-based study of the relationships among technological portfolio, ambidextrous innovation, and firm performance. Technol. Anal. Strateg. Manag. 2015, 27, 1193-1211. [CrossRef]

46. de Visser, M.; de Weerd-Nederhof, P.; Faems, D.; Song, M.; van Looy, B.; Visscher, K. Structural ambidexterity in NPD processes: A firm-level assessment of the impact of differentiated structures on innovation performance. Technovation 2010, 30, 291-299. [CrossRef]

47. Venkatraman, N.; Lee, C.-H.; Iyer, B. Strategic Ambidexterity and Sales Growth: A Longitudinal Test in the Software Sector; Boston University: Boston, MA, USA, 2007.

48. Lavie, D.; Kang, J.; Rosenkopf, L. Balance Within and Across Domains: The Performance Implications of Exploration and Exploitation in Alliances. Organ. Sci. 2011, 22, 1517-1538. [CrossRef]

49. Moreira, S.; Tae, C.J. The effect of industry leaders' exploratory innovation on competitor performance. Ind. Innov. 2019, 1-23. [CrossRef]

50. Simsek, Z. Organizational Ambidexterity: Towards a Multilevel Understanding. J. Manag. Stud. 2009, 46, 597-624. [CrossRef] 
51. McGrath, R.G. Exploratory learning, innovative capacity, and managerial oversight. Acad. Manag. J. 2001, 44, 118-131.

52. Siggelkow, N.; Levinthal, D.A. Temporarily Divide to Conquer: Centralized, Decentralized, and Reintegrated Organizational Approaches to Exploration and Adaptation. Organ. Sci. 2003, 14, 650-669. [CrossRef]

53. Powell, W.W.; Koput, K.W.; Smith-Doerr, L. Interorganizational Collaboration and the Locus of Innovation: Networks of Learning in Biotechnology. Adm. Sci. Q. 1996, 41, 116. [CrossRef]

54. Rosenkopf, L.; Nerkar, A. Beyond local search: Boundary-spanning, exploration, and impact in the optical disk industry. Strateg. Manag. J. 2001, 22, 287-306. [CrossRef]

55. Hong, J.; Hou, B.; Zhu, K.; Marinova, D. Exploratory innovation, exploitative innovation and employee creativity: The moderation of collectivism in Chinese context. Chin. Manag. Stud. 2018, 12, 268-286. [CrossRef]

56. Baum, J.A.C.; Li, S.X.; Usher, J.M. Making the Next Move: How Experiential and Vicarious Learning Shape the Locations of Chains' Acquisitions. Adm. Sci. Q. 2000, 45, 766-801. [CrossRef]

57. Lichtenthaler, U.; Lichtenthaler, E. A Capability-Based Framework for Open Innovation: Complementing Absorptive Capacity. J. Manag. Stud. 2009, 46, 1315-1338. [CrossRef]

58. Li, Y.; Vanhaverbeke, W.; Schoenmakers, W. Exploration and Exploitation in Innovation: Reframing the Interpretation. Creat. Innov. Manag. 2008, 17, 107-126. [CrossRef]

59. Benner, M.J.; Tushman, M.L. Exploitation, Exploration, and Process Management: The Productivity Dilemma Revisited. Acad. Manag. Rev. 2003, 28, 238-256. [CrossRef]

60. Zawislak, P.A.; Fracasso, E.M.; Tello-Gamarra, J. Technological intensity and innovation capability in industrial firms. Innov. Manag. Rev. 2018, 15, 189-207. [CrossRef]

61. Afshar Jahanshahi, A.; Brem, A. Entrepreneurs in post-sanctions Iran: Innovation or imitation under conditions of perceived environmental uncertainty? Asia Pacific J. Manag. 2019, 1-21. [CrossRef]

62. Tang, M.; Walsh, G.; Lerner, D.; Fitza, M.A.; Li, Q. Green Innovation, Managerial Concern and Firm Performance: An Empirical Study. Bus. Strateg. Environ. 2018, 27, 39-51. [CrossRef]

63. Jansen, J.J.P.; Van Den Bosch, F.A.J.; Volberda, H.W. Exploratory innovation, exploitative innovation, and performance: Effects of organizational antecedents and environmental moderators. Manage. Sci. 2006, 52, 1661-1674. [CrossRef]

64. Belsley, D.A.; Kuh, E.; Welsch, R.E. Regression Diagnostics: Identifying Influential Data and Sources of Collinearity; Wiley: Hoboken, NJ, USA, 1980; ISBN 9780471725152.

65. Hatzichronoglou, T. Revision of the High-Technology Sector and Product Classification; OECD Science, Technology and Industry: Paris, France, 1997.

66. Caloffi, A.; Mariani, M.; Rossi, F.; Russo, M. A comparative evaluation of regional subsidies for collaborative and individual R\&D in small and medium-sized enterprises. Res. Policy 2018, 47, 1437-1447. [CrossRef]

67. Brem, A. Creativity and routine: Conceptual considerations on managing organisational ambidexterity in entrepreneurial ventures. Int. J. Entrep. Innov. Manag. 2017, 21, 261-273. [CrossRef]

68. Jansen, J.J.P.; Vera, D.; Crossan, M. Strategic leadership for exploration and exploitation: The moderating role of environmental dynamism. Leadersh. Q. 2009, 20, 5-18. [CrossRef]

69. Ou, A.Y.; Waldman, D.A.; Peterson, S.J. Do Humble CEOs Matter? An Examination of CEO Humility and Firm Outcomes. J. Manag. 2018, 44, 1147-1173. [CrossRef]

70. Sinha, S. The Exploration-Exploitation Dilemma: A Review in the Context of Managing Growth of New Ventures. Vikalpa J. Decis. Makers 2015, 40, 313-323. [CrossRef]

71. He, Z.-L.; Wong, P.-K. Exploration vs. Exploitation: An Empirical Test of the Ambidexterity Hypothesis. Organ. Sci. 2004, 15, 481-494. [CrossRef]

72. Cohen, W.; Levin, R.; Mowery, D. Firm Size and R\&D Intensity: A Re-Examination. J. Ind. Econ. 1987, 4, 543-565. [CrossRef]

(C) 2019 by the authors. Licensee MDPI, Basel, Switzerland. This article is an open access article distributed under the terms and conditions of the Creative Commons Attribution (CC BY) license (http://creativecommons.org/licenses/by/4.0/). 